OPEN ACCESS

Edited by:

Julio Villena,

Reference Centre for Lactobacilli (CERELA-CONICET), Argentina

Reviewed by:

Haruki Kitazawa,

Tohoku University, Japan Maria Guadalupe Vizoso Pinto, National University of Tucumán,

Argentina

*Correspondence: Linda J. Saif

saif.2@osu.edu

tPresent address: Kuldeep S. Chattha, Canadian Food Inspection Agency, Lethbridge, $A B$, Canada; Lulu Shao,

University of Pittsburgh, Hillman Cancer Center, Pittsburgh, PA, USA;

Anand Kumar

Genomics and Systems Biology, Bioscience Division, Los Alamos National Laboratory, Los Alamos, NM, USA

Specialty section:

This article was submitted to Microbial Immunology,

a section of the journal

Frontiers in Immunology

Received: 29 November 2016 Accepted: 08 March 2017 Published: 27 March 2017

Citation:

Kandasamy S, Vlasova AN, Fischer DD, Chattha KS, Shao L, Kumar A, Langel SN, Rauf A,

Huang $\mathrm{H}-\mathrm{C}$, Rajashekara $\mathrm{G}$ and

Saif $L J$ (2017) Unraveling the Differences between Gram-Positive and Gram-Negative Probiotics in Modulating Protective Immunity to Enteric Infections.

Front. Immunol. 8:334. doi: 10.3389/fimmu.2017.00334

\section{Unraveling the Differences between Gram-Positive and Gram-Negative Probiotics in Modulating Protective Immunity to Enteric Infections}

\author{
Sukumar Kandasamy, Anastasia N. Vlasova, David D. Fischer, Kuldeep S. Chatthat, \\ Lulu Shao ${ }^{\dagger}$, Anand Kumart, Stephanie N. Langel, Abdul Rauf, Huang-Chi Huang, \\ Gireesh Rajashekara and Linda J. Saif* \\ Food Animal Health Research Program (FAHRP), Veterinary Preventive Medicine Department, The Ohio Agricultural \\ Research and Development Center, The Ohio State University, Wooster, OH, USA
}

The role of intestinal microbiota and probiotics in prevention and treatment of infectious diseases, including diarrheal diseases in children and animal models, is increasingly recognized. Intestinal commensals play a major role in development of the immune system in neonates and in shaping host immune responses to pathogens. Lactobacilli spp. and Escherichia coli Nissle 1917 are two probiotics that are commonly used in children to treat various medical conditions including human rotavirus diarrhea and inflammatory bowel disease. Although the health benefits of probiotics have been confirmed, the specific effects of these established Gram-positive $(G+)$ and Gram-negative (G-) probiotics in modulating immunity against pathogens and disease are largely undefined. In this review, we discuss the differences between $\mathrm{G}+$ and $\mathrm{G}-$ probiotics/commensals in modulating the dynamics of selected infectious diseases and host immunity. These probiotics modulate the pathogenesis of infectious diseases and protective immunity against pathogens in a species- and strain-specific manner. Collectively, it appears that the selected $\mathrm{G}$ - probiotic is more effective than the various tested $\mathrm{G}+$ probiotics in enhancing protective immunity against rotavirus in the gnotobiotic piglet model.

Keywords: rotavirus, probiotics, Escherichia coli Nissle, Lactobacillus, immunity, children, diarrhea, gnotobiotic piglet disease model

\section{INTRODUCTION}

Intestinal commensals constitute more than 1,000 species of bacteria. These commensals are involved in nutrient metabolism, development, and functioning of the gastrointestinal (GI) immune system and protection of the host from pathogens $(1-3)$. Colonization of the GI tract is a gradual process in which Escherichia coli and other enterobacteria colonize the intestinal tract early after birth, followed by the subsequent establishment of anaerobes (4). The intestinal microbiota of children only becomes adult-like at 2-3 years of age (5). Perturbation of the intestinal microbiota, or dysbiosis, is associated with various diseases such as inflammatory bowel disease (6) and also affects the efficacy of various vaccines in children (7). Probiotics are widely used to restore gut homeostasis in various medical conditions in humans (8-10) and treat diarrheal diseases in children. 
Diarrheal disease is one of the leading cause of deaths in children and it accounts for the death an estimated of 700,000 children annually worldwide (11). Specifically, rotavirus (RV) is a major cause of gastroenteritis in children worldwide. The protective efficacy of available RV vaccines is variable between regions and it is lowest in developing countries such as Southern Asia (50.0\%) and sub-Saharan Africa (46.1\%) (12). Additionally, lack of access to adequate health-care facilities to manage diarrhea is also associated with higher morbidity and mortality in children in low-income settings. Thus, enhancing vaccine efficacy, along with developing economical approaches to reduce the severity of RV diarrhea are effective strategies to ameliorate severe RV disease. Probiotics and intestinal commensals, crucial interacting partners of the gut immune system (13), are increasingly being considered for treatment of various enteric infections including human retrovirus (HRV) diarrhea (14), human norovirus gastroenteritis (15), antibiotic-associated diarrhea (16), and also to modulate protective antiviral immunity (17).

The beneficial effects of probiotics in reducing the severity of RV diarrhea and modulating viral immunity were observed in randomized clinical studies (18) and experimental studies in animal models (19) (Table 1). The Gram-positive (G+) Lactobacillus spp. were widely used to treat or prevent RV diarrhea in children. Specifically, prophylactic supplementation of Lactobacillus rhamnosus GG (LGG) to children significantly reduced the incidence of HRV disease (20). In our studies, gnotobiotic (Gn) piglets were used to study HRV pathogenesis due to their susceptibility to HRV infection and also the greater anatomic and physiological and immunological similarities between pigs and humans. Dual colonization of Gn piglets with G + LGG and Bifidobacterium lactis $\mathrm{Bb} 12$ resulted in a significant reduction in both fecal HRV shedding titers and diarrhea severity (21). Further, Lactobacillus strains have significant effects in reducing diarrhea severity in children affected by enteric diseases (22).

The effectiveness of probiotics in preventing or treating a disease is dependent on several factors such as class or strains of probiotics, the dosage of probiotics, and heterogeneity of study subjects $(40,41)$. Several past studies showed strain-specific differences of probiotics in modulating host immune responses (42). Thus, comparative analysis of the health benefits of different classes of probiotics is essential to tailor an effective regimen of probiotic treatment for a disease condition. Specifically variations in microbe-associated molecular patterns between $\mathrm{G}+$ and Gram-negative $(\mathrm{G}-)$ bacteria have been attributed to differential induction of innate immunity in a host $(43,44)$. However, limited studies have been conducted to decipher if differences exist between $\mathrm{G}+$ and $\mathrm{G}-$ probiotics in modulating host responses to infectious diseases. In our recent studies $(31,32)$, we compared the beneficial effects of $\mathrm{G}+$ and $\mathrm{G}-$ probiotics in modulating virulent HRV infection as well as host immunity. Specifically, LGG was selected as a $\mathrm{G}+$ probiotic because of its well-documented effects in reducing the severity of RV diarrhea in children (24). For the G- probiotic, we selected Escherichia coli Nissle 1917 (EcN) due to its proven effects in attenuating inflammatory disorders and modulating immunity in humans (45). In this review, we focused on the comparisons of the health benefits of G+ and G- probiotics in modulating microbial infections and immunity.

\section{EFFECTS OF G+ VERSUS G- PROBIOTICS ON ENTERIC INFECTIONS AND DIARRHEA}

Probiotics have been successfully used to prevent or treat enteric infections in children and animals (Table 1). One notable finding is the difference between $\mathrm{G}+$ and $\mathrm{G}-$ probiotics in modulating host immunity against microbial diseases. In one study (31), the comparative efficacy of LGG and EcN probiotics in ameliorating HRV disease was assessed in Gn piglets. The EcN colonized piglets had reduced diarrhea severity and also lower mean peak virus shedding titers compared with LGG or uncolonized piglets post-virulent human RV (VirHRV) challenge $(31,32)$. Both EcN and LGG showed similar colonization patterns as indicated by comparable fecal shedding of each bacterium and also detection of similar levels of each probiotic bacteria in various sections of GI tract. Similarly, EcN supplementation to children with enteric infections resulted in reduced duration of diarrhea (26). Further, supplementation of $\mathrm{EcN}$ to infants for the first 5 days immediately after birth resulted in persistence of the probiotic for 6 months as indicated by fecal shedding of $\mathrm{EcN}$ (29). Similar to the higher beneficial effects of EcN than LGG on ameliorating HRV infection, higher protective effects against Salmonella were observed in EcN compared with Bifidobacterium choerinum-supplemented $\mathrm{Gn}$ piglets (30). The higher protective effect of $\mathrm{EcN}$ against Salmonella was associated with increased expression of ZO-1 and occludin in ileal epithelial cells and decreased inflammatory TNF- $\alpha$ cytokine levels in the EcN colonized Gn piglets (30). Consistent with these findings, higher TNF- $\alpha$ levels were induced by $\mathrm{G}+$ commensals as compared with $\mathrm{G}-$ commensals using in vitro mononuclear cultures (43). EcN supplementation also attenuated lipopolysaccharides (LPS) or trinitrobenzene sulfonic acid-induced inflammatory conditions in a mouse model (46). In summary, the higher ability of G- compared with $\mathrm{G}+$ probiotics in reducing the levels of inflammatory mediators during enteric infections may be major contributing factor in reducing diarrhea severity.

\section{G+ and G- Probiotic Impacts on Modulation of B Cell Responses}

Microbial colonization of the GI tract has a significant effect on the maturation of neonatal immune system (47). Consistent with this observation, administration of $\mathrm{EcN}$ enhanced serum $\mathrm{EcN}$ specific IgA antibody and polyclonal IgM antibody responses in infants as compared with placebo group (28). Also, mono EcN or dual EcN + LGG colonization significantly increased serum total IgA and IgG responses compared with LGG colonized or uncolonized piglets (31) (Figure 1). Similar to systemic immunoglobulin responses, EcN colonization resulted in higher small intestinal total IgA responses compared with LGG colonization in Gn pigs. Thus, EcN had more potent immunostimulatory effects than LGG in terms of inducing mucosal and systemic B cell responses. The underlying mechanism for differential induction of antibody responses by $\mathrm{G}+$ and $\mathrm{G}-$ bacteria might be due to variation in IgA inducing factors such as IL-10 cytokine. In fact, $\mathrm{G}-$, but not $\mathrm{G}+$ probiotics, induced higher IL-10 responses in 
TABLE 1 | Effects of $\mathrm{G}+$ and $\mathrm{G}$ - probiotics on diarrheal diseases and immunity in children and animal models.

\begin{tabular}{|c|c|c|c|c|c|}
\hline $\begin{array}{l}\text { Gram-positive } \\
\text { probiotic/ } \\
\text { commensal } \\
\text { bacteria }\end{array}$ & $\begin{array}{l}\text { Gram-negative } \\
\text { probiotic/ } \\
\text { commensal } \\
\text { bacteria }\end{array}$ & $\begin{array}{l}\text { Humans/ } \\
\text { animal } \\
\text { model/in vitro } \\
\text { study }\end{array}$ & Indication & Conclusion(s) & Reference \\
\hline $\begin{array}{l}\text { L. rhamnosus GG } \\
\left(6 \times 10^{9} \mathrm{CFU} / \text { dose }\right)\end{array}$ & None & Children & Prophylaxis against diarrheal diseases & $\begin{array}{l}\text { Significant reduction in incidence of HRV } \\
\text { disease in LGG-supplemented group }\end{array}$ & $(20)$ \\
\hline $\begin{array}{l}\text { L. rhamnosus GG } \\
\left(10^{10-11} \mathrm{CFU}\right)\end{array}$ & None & Children & $\begin{array}{l}\text { Effect of LGG on immune responses to } \\
\text { HRV in children }\end{array}$ & $\begin{array}{l}\text { LGG significantly enhanced RV-specific IgA } \\
\text { antibody responses }\end{array}$ & (23) \\
\hline $\begin{array}{l}\text { L. rhamnosus GG } \\
\left(10^{10} \mathrm{CFU}\right)\end{array}$ & None & Children & Treating diarrhea & Reduced duration of diarrhea & (24) \\
\hline $\begin{array}{l}\text { Lactobacillus } \\
\text { paracasei strain ST11 } \\
\left(10^{10} \mathrm{CFU}\right)\end{array}$ & None & Children & Treating diarrhea & $\begin{array}{l}\text { Reduced severity of non-rotavirus induced } \\
\text { diarrhea but no effect on rotavirus diarrhea }\end{array}$ & $(25)$ \\
\hline None & $\begin{array}{l}\text { Escherichia coli } \\
\text { Nissle } 1917 \text { (EcN) } \\
\left(10^{8} \mathrm{CFU}\right)\end{array}$ & Children & Treat acute diarrhea in children & Reduced duration of diarrhea by 2.3 days & (26) \\
\hline None & $\operatorname{EcN}\left(3 \times 10^{8} \mathrm{CFU}\right)$ & Infants & $\begin{array}{l}\text { To assess effects on total IgA responses } \\
\text { in infants }\end{array}$ & Increased serum and stool IgA responses & $(27)$ \\
\hline None & EcN $\left(10^{8} \mathrm{CFU}\right)$ & Infants & $\begin{array}{l}\text { Assess impact on cellular and humoral } \\
\text { immunity in infants }\end{array}$ & $\begin{array}{l}\text { Probiotic increased both cellular proliferative } \\
\text { and serum total IgA responses }\end{array}$ & (28) \\
\hline None & EcN $\left(10^{8} \mathrm{CFU}\right)$ & Infants & $\begin{array}{l}\text { Prophylactic administration against } \\
\text { bacterial pathogens }\end{array}$ & $\begin{array}{l}\text { Significant reduction in bacterial pathogens in } \\
\text { fecal samples }\end{array}$ & (29) \\
\hline $\begin{array}{l}\text { Bifidobacterium } \\
\text { choerinum } \\
\left(5 \times 10^{8} \mathrm{CFU} / \mathrm{ml}\right)\end{array}$ & $\begin{array}{l}\mathrm{ECN}\left(5 \times 10^{8} \mathrm{CFU} /\right. \\
\mathrm{ml})\end{array}$ & Gn piglets & $\begin{array}{l}\text { Protection against Salmonella enterica } \\
\text { serovar Typhimurium infection }\end{array}$ & $\begin{array}{l}\text { EcN conferred higher protection against } \\
\text { disease than Bifidobacterium choerinum }\end{array}$ & $(30)$ \\
\hline $\begin{array}{l}\text { L. rhamnosus GG } \\
\left(10^{5} \mathrm{CFU} / \mathrm{ml}\right)\end{array}$ & $\mathrm{EcN}\left(10^{5} \mathrm{CFU} / \mathrm{ml}\right)$ & Gn piglets & $\begin{array}{l}\text { Compare } \mathrm{G}+\text { and } \mathrm{G}-\text { bacteria effect on } \\
\mathrm{HRV} \text { infection and immunity }\end{array}$ & $\begin{array}{l}\text { EcN was more effective than LGG in } \\
\text { ameliorating HRV disease and enhancing total } \\
\operatorname{lgA} \text { and NK cell responses }\end{array}$ & $(31,32)$ \\
\hline $\begin{array}{l}\text { L. rhamnosus } \\
\text { GG }\left(10^{5} \mathrm{CFU} / \mathrm{ml}\right) \\
\text { Bifidobacterium lactis } \\
\text { Bb12 }(105 \mathrm{CFU} / \mathrm{ml})\end{array}$ & None & Gn piglets & To study effects on HRV disease & $\begin{array}{l}\text { Reduced fecal virus shedding and diarrhea } \\
\text { severity in probiotic colonized piglets }\end{array}$ & $(21)$ \\
\hline $\begin{array}{l}\text { Enterococcus faecium } \\
\text { NCIMB } 10415 \\
\left(4.2-4.3 \times 10^{6} / \mathrm{g} \mathrm{CFU}\right)\end{array}$ & None & $\begin{array}{l}\text { Sows and their } \\
\text { offspring }\end{array}$ & $\begin{array}{l}\text { Effect on fecal shedding of enteric } \\
\text { viruses }\end{array}$ & $\begin{array}{l}\text { Reduced fecal shedding of rotavirus } \\
\text { and increased rotavirus specific IgA } \\
\text { responses. No effect on hepatitis E virus, } \\
\text { encephalomyocarditis virus, and norovirus } \\
\text { shedding in feces }\end{array}$ & (33) \\
\hline None & EcN $\left(10^{10} \mathrm{CFU} / \mathrm{ml}\right)$ & Pigs & $\begin{array}{l}\text { To prevent enterotoxigenic Escherichia } \\
\text { coli induced diarrhea }\end{array}$ & Ameliorated clinical signs of diarrhea & (34) \\
\hline None & $\mathrm{ECN}\left(10^{8} \mathrm{CFU} / \mathrm{ml}\right)$ & Neonatal calf & Prevention and treatment of diarrhea & $\begin{array}{l}\text { Reduction in incidence of diarrheal diseases } \\
\text { in prophylactic group. Ameliorated severity of } \\
\text { diarrhea in calves with enteric diseases }\end{array}$ & (35) \\
\hline $\begin{array}{l}\text { Lactobacillus } \\
\text { acidophilus A9 }\left(10^{8} /\right. \\
\text { ml CFU) }\end{array}$ & $\begin{array}{l}\text { Escherichia coli } \\
13-7\left(10^{6} / \mathrm{ml} \mathrm{CFU}\right)\end{array}$ & Mice & $\begin{array}{l}\text { Compare } \mathrm{G}+\text { and } \mathrm{G}-\text { bacteria effect on } \\
\text { cytokine responses in mice }\end{array}$ & $\begin{array}{l}\text { E. coli } 13-7 \text { induced higher IL-12 cytokine } \\
\text { compared to L. acidophilus A9 }\end{array}$ & (36) \\
\hline None & $\begin{array}{l}\mathrm{ECN} \\
\left(1.5-2 \times 10^{8} \mathrm{CFU}\right)\end{array}$ & Mice & $\begin{array}{l}\text { Assess impact on intestinal barrier } \\
\text { function in acute dextran sodium sulfate- } \\
\text { induced colitis }\end{array}$ & Strengthened intestinal barrier function & $(37)$ \\
\hline $\begin{array}{l}\text { Lactobacillus casei } \\
\text { Shirota }\end{array}$ & EcN & In vitro & Investigate effects on innate immunity & $\begin{array}{l}\text { Higher IL-10 and IL-12 induction by EcN than } \\
\text { L. casei Shirota }\end{array}$ & (38) \\
\hline $\begin{array}{l}\text { L. plantarum, L. } \\
\text { rhamnosus, L. } \\
\text { paracasei ssp. } \\
\text { paracasei }\end{array}$ & $\begin{array}{l}\text { Escherichia coli } \\
\text { O6:K13:H1, } \\
\text { Escherichia coli } \\
\text { MS101 }\end{array}$ & In vitro & $\begin{array}{l}\text { Compare } \mathrm{G}+\text { and } \mathrm{G} \text { - bacteria effect on } \\
\text { cytokine responses of monocytes }\end{array}$ & Lactobacilli-induced higher level of IL-12 & (39) \\
\hline
\end{tabular}




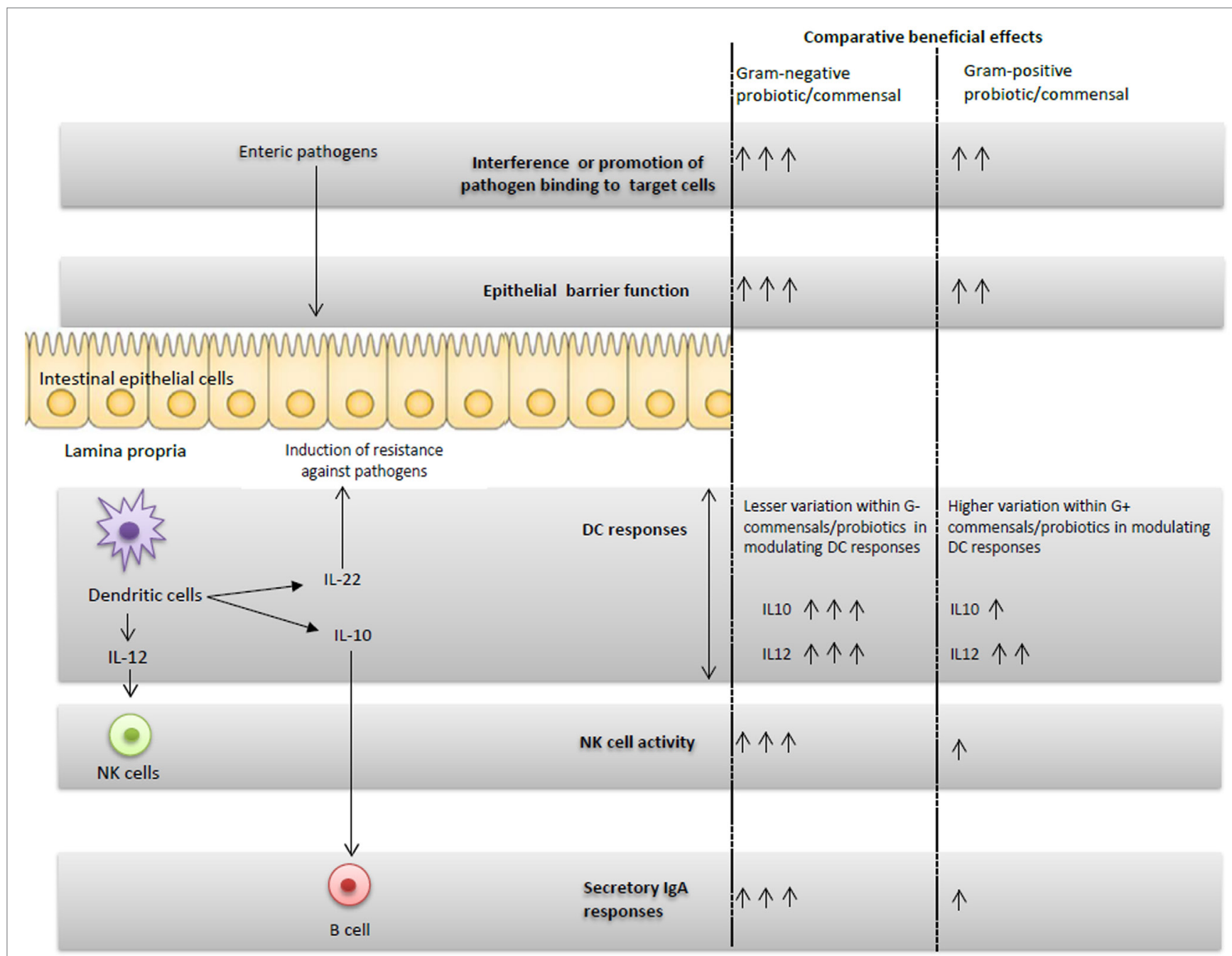

FIGURE 1 | Schematic representation of the G+ and G- probiotics-induced immunomodulatory effects and proposed potential immune interactions.

prior studies $(31,48,49)$. IL-10 is one of the cytokines that mediates the induction of $\operatorname{IgA}$ antibody responses at mucosal sites through enhancing antibody class switching (50). Differences in the microbe-associated molecular patterns between the probiotics might be a potential reason for the differential induction of IL-10 by G+ and G- bacteria. Indeed, both the LPS portion of $\mathrm{EcN}$ and whole EcN lysate were identified as potent inducers of IL-10 production in peripheral blood mononuclear cells (51). Further, induction of total $\operatorname{Ig} \mathrm{A}$ responses is at least partially mediated by IL-10 in vitro (31). These studies demonstrate that modulation of the cytokine milieu, such as enhanced IL-10 levels, might be a potential mechanism to account for the higher antibody responses observed in $\mathrm{G}-$ compared with $\mathrm{G}+$ probiotics groups.

It is also well established that strain-dependent variations in immunomodulatory properties are observed within G+ probiotics (52). Thus, individual probiotic strains within $\mathrm{G}+$ or G- probiotic classes may differ in modulating antibody responses. Consequently, screening of the beneficial effects of individual probiotics is essential to elucidate their impacts on antibody responses.

\section{Impact of Innate Immunity on IgA Responses to $\mathbf{G}+$ versus $\mathbf{G}-$ Probiotics}

Innate immunity plays an integral role in priming the adaptive immune responses. Thus, probiotics may induce specific changes in innate immunity that may be involved in synergistically enhancing IgA responses. Dual colonization of a $\mathrm{G}-$ and $\mathrm{G}+$ probiotic enhanced serum total IgA responses in Gn piglets compared with mono-colonization of the probiotics (31). Thus, G+ and G- bacteria synergistically enhanced the systemic total IgA responses. In fact, combinations of $\mathrm{G}+$ and $\mathrm{G}-$ probiotics had additive effects on induction of maturation markers in DCs as well as levels of IL-10 cytokines (53). Thus, considering the known function of DCs in induction of IgA responses $(54,55)$, the positive effects of combinations of G+ and G- bacteria in modulating DCs may play a role in enhancing $\operatorname{IgA}$ responses. Additionally, a previous 
study (56) also showed that LPS, a TLR4 ligand, synergistically interacted with TLR1/2 ligands which in turn enhanced classswitch recombination in B cells. Thus, synergistic interactions of microbe-associated molecular patterns from $\mathrm{G}-$ and $\mathrm{G}+$ probiotics might also play a role in enhancing antibody responses. Apart from DCs, it appears that intestinal epithelial cells also respond differently in terms of producing IgA mediators such as TGF- $\beta$ and thymic stromal lymphopoietin (TSLP). Specifically, G- commensals induce higher production of TGF- $\beta$ and TSLP as compared with G+ commensals (57). Further, higher frequencies of splenic TLR9 ${ }^{+}$mononuclear cells were detected in EcN + LGG colonized compared with the monocolonized EcN or LGG Gn piglets (32). TLR9 recognizes CpG DNA and LGG has a high GC percentage in its genomic DNA (58). Thus, we speculate that higher systemic TLR9 expression in EcN + LGG compared with $\mathrm{EcN}$ or LGG monocolonized piglets might be a contributing factor in enhancing immunoglobulin responses as reported in several earlier studies $(59,60)$.

One unanswered question is the involvement of total IgA levels in modulating immunopathology during microbial infections. Previous studies have shown the involvement of IgA in moderating inflammatory responses through modulating dendritic cells and regulatory $\mathrm{T}$ cell functions $(61,62)$. Further, secretory IgA-commensal complexes were shown to reduce inflammatory responses in intestinal epithelial cells (63). Thus, the role of secretory IgA in mitigating infection-induced inflammatory responses is intriguing and requires further investigation.

\section{Differential Effects of $\mathbf{G}+$ versus $\mathrm{G}-$ Probiotics in Modulating Innate Immunity}

Probiotics may elicit their beneficial effects against pathogens through modulating innate immunity. A role for innate immunity in mediating host defenses against enteric diseases including RV infection has been elucidated in recent studies (64-67). Specifically, functions of dendritic cells are modulated by various probiotics. It appears that DC populations in the intestine can be modulated by intestinal commensals. This concept is supported by results of an investigation in which depletion of intestinal microbiota resulted in a reduction in DCs numbers in mucosal compartments as well as impaired resistance against influenza virus infection in mice (68). Additionally, G- commensal bacteria have higher immunostimulatory effects on DCs as compared with G+ commensals (69). For example, G- EcN increased frequencies of total plasmacytoid dendritic cells (pDCs) and activated pDCs, more than the G+ LGG probiotic in Gn piglets (32). Also, G- commensals were highly potent in the induction of maturation markers in DCs as compared with G+ commensals (53). Importantly, greater variation was observed among $\mathrm{G}+$ commensals in modulating DC responses, compared with less variation among G- commensals (53). Thus, the distinct ability of G- bacteria such as $\mathrm{EcN}$ in modulating frequencies and functions of DCs may have beneficial impacts on induction of protective immunity against pathogens.

In our recently published study (32), we observed higher NK cytotoxic function and increased frequencies of pDCs in $\mathrm{EcN}$ colonized compared with LGG colonized or uncolonized piglets.
The enhanced NK cell activity coincided with higher serum IL-12 levels in vivo in EcN colonized piglets (Figure 1) and also DC production of IL-12 in vitro (32). Similar to our studies, treatment of murine bone marrow-derived DCs (BMDCs) with EcN resulted in induction of IL-12 and IL-10 cytokines and induction of activation markers in BMDCs (70). In the same study, EcN administration reduced the development of allergen-specific Th2 responses (70). Thus, our results showed that NK cell function can be modulated by probiotics, and more importantly, only G- EcN but not G+ LGG, enhanced NK cell function. These findings were further corroborated by an earlier study in which the germ-free condition impaired the priming of NK cell function by microbial ligands (71). Further, the reduced NK cell function in microbiota-depleted mice was correlated with higher mouse cytomegalovirus titers post-viral challenge (71). A recent study (72) also showed the potential role of the outer membrane vesicles from $\mathrm{EcN}$ in induction of IL-22 cytokine responses. IL-22, along with IFN- $\lambda$, has been shown to effectively reduce $\mathrm{RV}$ replication in a mouse model (66). These results underscore not only the importance of intestinal commensals in regulating innate immunity against viral infections, but also the differential abilities of distinct known $\mathrm{G}+$ or $\mathrm{G}-$ probiotics in regulating innate immune cells.

\section{Interactions between Commensals and Viruses That Alter Their Pathogenesis}

Direct interactions between viruses and bacteria are being increasingly investigated in recent studies (73-75). Specifically, direct binding of commensal microbiota is associated with either increased or decreased viral infections (76). The ability of mouse mammary tumor virus to bind with LPS was associated with increased virus pathogenicity (77). Similarly, poliovirus stability and viral attachment to target host cells were also enhanced by interaction with bacterial LPS or peptidoglycan (78). Further, EcN binds to HRV ex vivo but no such interaction was found between LGG and HRV (31). Also, in this study, prior treatment of epithelial cells with EcN, but not LGG, resulted in a significant reduction in the epithelial attachment of HRV in vitro. Further studies are required to elucidate the potential role of physical interactions between $\mathrm{EcN}$ and viruses in terms of altering the course of viral infection and pathogenicity. Expression of histo-blood group antigens (HBGA) was observed in some $\mathrm{G}-$ intestinal commensal bacteria (79) and certain of those HBGA-expressing bacteria were shown to enhance (73) enteric viral infection. Considering the direct interactions between the commensals and pathogens, any disturbances in microbiota compositions may lead to altered susceptibility or resistance to a particular enteric pathogen. Thus, further studies are required to assess whether any difference exists between $\mathrm{G}+$ and $\mathrm{G}-$ bacteria in binding properties with various enteric viruses and the impact on the course of viral pathogenicity.

\section{CONCLUSION}

Comparison of the beneficial effects of $\mathrm{G}+$ and $\mathrm{G}-$ probiotics and intestinal commensals indicated that the selected $\mathrm{G}-$ probiotic 
had higher beneficial effects in inducing protective immunity against enteric pathogens such as HRV as compared with the selected G+ probiotics in humans and animal models. In our simplified in vivo $\mathrm{Gn}$ piglet model system, it appears that the induced beneficial effects of G- EcN against HRV disease may be accomplished by the integrated interaction of DCs, NK cells, and immunoglobulins as well as direct binding of $\mathrm{EcN}$ to virus (Figure 1). Most of the initial studies showed that $\mathrm{G}-$ probiotics have higher immunostimulatory effects and better protective effects against HRV as compared with $\mathrm{G}+$ probiotics. It remains to be determined whether these findings can be generalized to all $\mathrm{G}-$ commensals. Further, the potential ability of different G+ and $\mathrm{G}$ - probiotics to alter the composition as well as functionalities of the intestinal microbiota, and the consequences of these changes on microbial infections and vaccines is unclear. Identification of the essential components of probiotics that induce the beneficial

\section{REFERENCES}

1. Nicholson JK, Holmes E, Kinross J, Burcelin R, Gibson G, Jia W, et al. Host-gut microbiota metabolic interactions. Science (2012) 336:1262-7. doi:10.1126/ science. 1223813

2. Kamada N, Chen GY, Inohara N, Nunez G. Control of pathogens and pathobionts by the gut microbiota. Nat Immunol (2013) 14:685-90. doi:10.1038/ ni.2608

3. Kamada N, Nunez G. Role of the gut microbiota in the development and function of lymphoid cells. J Immunol (2013) 190:1389-95. doi:10.4049/ jimmunol.1203100

4. Scholtens PA, Oozeer R, Martin R, Amor KB, Knol J. The early settlers: intestinal microbiology in early life. Annu Rev Food Sci Technol (2012) 3:425-47. doi:10.1146/annurev-food-022811-101120

5. Yatsunenko T, Rey FE, Manary MJ, Trehan I, Dominguez-Bello MG, Contreras $\mathrm{M}$, et al. Human gut microbiome viewed across age and geography. Nature (2012) 486:222-7. doi:10.1038/nature11053

6. Arrieta MC, Stiemsma LT, Amenyogbe N, Brown EM, Finlay B. The intestinal microbiome in early life: health and disease. Front Immunol (2014) 5:427. doi:10.3389/fimmu.2014.00427

7. Huda MN, Lewis Z, Kalanetra KM, Rashid M, Ahmad SM, Raqib R, et al. Stool microbiota and vaccine responses of infants. Pediatrics (2014) 134:e362-72. doi:10.1542/peds.2013-3937

8. Huang JS, Bousvaros A, Lee JW, Diaz A, Davidson EJ. Efficacy of probiotic use in acute diarrhea in children: a meta-analysis. Dig Dis Sci (2002) 47:2625-34. doi:10.1023/A:1020501202369

9. Engelbrektson A, Korzenik JR, Pittler A, Sanders ME, Klaenhammer TR, Leyer G, et al. Probiotics to minimize the disruption of faecal microbiota in healthy subjects undergoing antibiotic therapy. J Med Microbiol (2009) 58:663-70. doi:10.1099/jmm.0.47615-0

10. Pagnini C, Saeed R, Bamias G, Arseneau KO, Pizarro TT, Cominelli F. Probiotics promote gut health through stimulation of epithelial innate immunity. Proc Natl Acad Sci U S A (2010) 107:454-9. doi:10.1073/pnas. 0910307107

11. Walker CLF, Rudan I, Liu L, Nair H, Theodoratou E, Bhutta ZA, et al. Global burden of childhood pneumonia and diarrhoea. Lancet (2013) 381:1405-16. doi:10.1016/S0140-6736(13)60222-6

12. Lamberti LM, Ashraf S, Walker C, Black RE. A systematic review of the effect of rotavirus vaccination on diarrhea outcomes among children younger than 5 years. Pediatr Infect Dis J (2016) 35(9):992-8. doi:10.1097/ INF.0000000000001232

13. Round JL, Mazmanian SK. The gut microbiota shapes intestinal immune responses during health and disease. Nat Rev Immunol (2009) 9:313-23. doi:10.1038/nri2515

14. Majamaa H, Isolauri E, Saxelin M, Vesikari T. Lactic acid bacteria in the treatment of acute rotavirus gastroenteritis. J Pediatr Gastroenterol Nutr (1995) 20:333-8. doi:10.1097/00005176-199504000-00012 effects against pathogens may also be useful in identifying probiotics or their products as novel adjuvants for vaccines.

\section{AUTHOR CONTRIBUTIONS}

All authors listed have made substantial direct contribution to the work.

\section{ACKNOWLEDGMENTS}

This work was supported by a grant from the NIAID, NIH (grant \# R01 A1099451 to LJS, AV, and GR) and federal funds appropriated to the Ohio Agricultural Research and Development Center (OARDC) of The Ohio State University. The authors thank Dr. J. Hanson, R. Wood, and J. Ogg, J. Chepngeno, and K. Scheuer for their technical assistance.

15. Nagata S, Asahara T, Ohta T, Yamada T, Kondo S, Bian L, et al. Effect of the continuous intake of probiotic-fermented milk containing Lactobacillus casei strain Shirota on fever in a mass outbreak of norovirus gastroenteritis and the faecal microflora in a health service facility for the aged. Br J Nutr (2011) 106:549-56. doi:10.1017/S000711451100064X

16. McFarland LV. Meta-analysis of probiotics for the prevention of antibiotic associated diarrhea and the treatment of Clostridium difficile disease. Am J Gastroenterol (2006) 101:812-22. doi:10.1111/j.1572-0241.2006. 00465.x

17. Sindhu KN, Sowmyanarayanan TV, Paul A, Babji S, Ajjampur SS, Priyadarshini $\mathrm{S}$, et al. Immune response and intestinal permeability in children with acute gastroenteritis treated with Lactobacillus rhamnosus GG: a randomized, double-blind, placebo-controlled trial. Clin Infect Dis (2014) 58:1107-15. doi:10.1093/cid/ciu065

18. Sanders ME, Guarner F, Guerrant R, Holt PR, Quigley EM, Sartor RB, et al. An update on the use and investigation of probiotics in health and disease. Gut (2013) 62:787-96. doi:10.1136/gutjnl-2012-302504

19. Vlasova AN, Kandasamy S, Chattha KS, Rajashekara G, Saif LJ. Comparison of probiotic lactobacilli and bifidobacteria effects, immune responses and rotavirus vaccines and infection in different host species. Vet Immunol Immunopathol (2016) 172:72-84. doi:10.1016/j.vetimm.2016. 01.003

20. Szajewska H, Kotowska M, Mrukowicz JZ, Arma M, Mikolajczyk W. Efficacy of Lactobacillus GG in prevention of nosocomial diarrhea in infants. J Pediatr (2001) 138:361-5. doi:10.1067/mpd.2001.111321

21. Chattha KS, Vlasova AN, Kandasamy S, Rajashekara G, Saif LJ. Divergent immunomodulating effects of probiotics on $\mathrm{T}$ cell responses to oral attenuated human rotavirus vaccine and virulent human rotavirus infection in a neonatal gnotobiotic piglet disease model. J Immunol (2013) 191:2446-56. doi:10.4049/ jimmunol.1300678

22. Rosenfeldt V, Michaelsen KF, Jakobsen M, Larsen CN, Møller PL, Pedersen P, et al. Effect of probiotic Lactobacillus strains in young children hospitalized with acute diarrhea. Pediatr Infect Dis J (2002) 21:411-6. doi:10.1097/00006454-200205000-00012

23. Kaila M, Isolauri E, Saxelin M, Arvilommi H, Vesikari T. Viable versus inactivated Lactobacillus strain GG in acute rotavirus diarrhoea. Arch Dis Child (1995) 72:51-3. doi:10.1136/adc.72.1.51

24. Guandalini S, Pensabene L, Zikri MA, Dias JA, Casali LG, Hoekstra H, et al Lactobacillus GG administered in oral rehydration solution to children with acute diarrhea: a multicenter European trial. J Pediatr Gastroenterol Nutr (2000) 30:54-60. doi:10.1097/00005176-200001000-00018

25. Sarker SA, Sultana S, Fuchs GJ, Alam NH, Azim T, Brüssow H, et al. Lactobacillus paracasei strain ST11 has no effect on rotavirus but ameliorates the outcome of nonrotavirus diarrhea in children from Bangladesh. Pediatrics (2005) 116:e221-8. doi:10.1542/peds.2004-2334

26. Henker J, Laass M, Blokhin BM, Bolbot YK, Maydannik VG, Elze M, et al. The probiotic Escherichia coli strain Nissle $1917(\mathrm{EcN})$ stops acute 
diarrhoea in infants and toddlers. Eur J Pediatr (2007) 166:311-8. doi:10.1007/ s00431-007-0419-x

27. Lodinová-Žaadniková R, Tlaskalová-Hogenová H, Sonnenborn U. Local and serum antibody response in full-term and premature infants after artificial colonization of the intestine with E. coli strain Nissle 1917 (Mutaflor ${ }^{\circledR}$ ). Pediatr Allergy Immunol (1992) 3:43-8. doi:10.1111/j.1399-3038.1992. tb00026.x

28. Cukrowska B, Lodínová-Žádníková R, Enders C, Sonnenborn U, Schulze J, Tlaskalová-Hogenová H. Specific proliferative and antibody responses of premature infants to intestinal colonization with nonpathogenic probiotic E. coli strain Nissle 1917. Scand JImmunol (2002) 55:204-9. doi:10.1046/j.1365-3083.2002.01005.x

29. Lodinová-Žádníková R, Sonnenborn U. Effect of preventive administration of a nonpathogenic Escherichia coli strain on the colonization of the intestine with microbial pathogens in newborn infants. Neonatology (1997) 71:224-32. doi:10.1159/000244421

30. Splichalova A, Trebichavsky I, Rada V, Vlkova E, Sonnenborn U, Splichal I. Interference of Bifidobacterium choerinum or Escherichia coli Nissle 1917 with Salmonella typhimurium in gnotobiotic piglets correlates with cytokine patterns in blood and intestine. Clin Exp Immunol (2011) 163:242-9. doi:10.1111/j.1365-2249.2010.04283.x

31. Kandasamy S, Vlasova AN, Fischer D, Kumar A, Chattha KS, Rauf A, et al. Differential effects of Escherichia coli Nissle and Lactobacillus rhamnosus strain GG on human rotavirus binding, infection, and B cell immunity. J Immunol (2016) 196:1780-9. doi:10.4049/jimmunol.1501705

32. Vlasova AN, Shao L, Kandasamy S, Fischer DD, Rauf A, Langel SN, et al. Escherichia coli Nissle 1917 protects gnotobiotic pigs against human rotavirus by modulating pDC and NK-cell responses. Eur J Immunol (2016) 46(10):2426-37. doi:10.1002/eji.201646498

33. Kreuzer S, Machnowska P, Aßmus J, Sieber M, Pieper R, Schmidt MF, et al. Feeding of the probiotic bacterium Enterococcus faecium NCIMB 10415 differentially affects shedding of enteric viruses in pigs. Vet Res (2012) 43:1. doi:10.1186/1297-9716-43-58

34. Schroeder B, Duncker S, Barth S, Bauerfeind R, Gruber A, Deppenmeier S, et al. Preventive effects of the probiotic Escherichia coli strain Nissle 1917 on acute secretory diarrhea in a pig model of intestinal infection. Dig Dis Sci (2006) 51:724-31. doi:10.1007/s10620-006-3198-8

35. Von Buenau R, Jaekel L, Schubotz E, Schwarz S, Stroff T, Krueger M. Escherichia coli strain Nissle 1917: significant reduction of neonatal calf diarrhea. J Dairy Sci (2005) 88:317-23. doi:10.3168/jds.S0022-0302(05)72690-4

36. Dogi C, Galdeano CM, Perdigón G. Gut immune stimulation by non pathogenic Gram (+) and Gram (-) bacteria. Comparison with a probiotic strain. Cytokine (2008) 41:223-31. doi:10.1016/j.cyto.2007.11.014

37. Ukena SN, Singh A, Dringenberg U, Engelhardt R, Seidler U, Hansen W, et al. Probiotic Escherichia coli Nissle 1917 inhibits leaky gut by enhancing mucosal integrity. PLoS One (2007) 2:e1308. doi:10.1371/journal.pone. 0001308

38. Cross ML, Ganner A, Teilab D, Fray LM. Patterns of cytokine induction by Gram-positive and Gram-negative probiotic bacteria. FEMS Immunol Med Microbiol (2004) 42:173-80. doi:10.1016/j.femsim.2004.04.001

39. Hessle C, Hanson L, Wold AE. Lactobacilli from human gastrointestinal mucosa are strong stimulators of IL-12 production. Clin Exp Immunol (1999) 116:276-82. doi:10.1046/j.1365-2249.1999.00885.x

40. Boyle RJ, Robins-Browne RM, Tang ML. Probiotic use in clinical practice: what are the risks? Am J Clin Nutr (2006) 83:1256-64.

41. Özdemir Ö. Various effects of different probiotic strains in allergic disorders: an update from laboratory and clinical data. Clin Exp Immunol (2010) 160:295-304. doi:10.1111/j.1365-2249.2010.04109.x

42. MénardO, ButelM-J,Gaboriau-Routhiau V,Waligora-DuprietA-J. Gnotobiotic mouse immune response induced by Bifidobacterium sp. strains isolated from infants. Appl Environ Microbiol (2008) 74:660-6. doi:10.1128/AEM. 01261-07

43. Karlsson H, Hessle C, Rudin A. Innate immune responses of human neonatal cells to bacteria from the normal gastrointestinal flora. Infect Immun (2002) 70:6688-96. doi:10.1128/IAI.70.12.6688-6696.2002

44. Qi H, Denning TL, Soong L. Differential induction of interleukin-10 and interleukin-12 in dendritic cells by microbial toll-like receptor activators and skewing of T-cell cytokine profiles. Infect Immun (2003) 71:3337-42. doi:10.1128/IAI.71.6.3337-3342.2003
45. Sonnenborn U, Schulze J. The non-pathogenic Escherichia coli strain Nissle 1917-features of a versatile probiotic. Microb Ecol Health Dis (2009) 21:122-58. doi:10.3109/08910600903444267

46. Arribas B, Rodríguez-Cabezas M, Camuesco D, Comalada M, Bailón E, Utrilla P, et al. A probiotic strain of Escherichia coli, Nissle 1917, given orally exerts local and systemic anti-inflammatory effects in lipopolysaccharide-induced sepsis in mice. Br J Pharmacol (2009) 157:1024-33. doi:10.1111/j.1476-5381.2009.00270.x

47. Macpherson AJ, Harris NL. Interactions between commensal intestinal bacteria and the immune system. Nat Rev Immunol (2004) 4:478-85. doi:10.1038/ nri1373

48. Hessle C, Andersson B, Wold AE. Gram-positive bacteria are potent inducers of monocytic interleukin-12 (IL-12) while Gram-negative bacteria preferentially stimulate IL-10 production. Infect Immun (2000) 68:3581-6. doi:10.1128/IAI.68.6.3581-3586.2000

49. Surbatovic M, Popovic N, Vojvodic D, Milosevic I, Acimovic G, Stojicic M, et al. Cytokine profile in severe Gram-positive and Gram-negative abdominal sepsis. Sci Rep (2015) 5:11355. doi:10.1038/srep11355

50. Cerutti A, Rescigno M. The biology of intestinal immunoglobulin A responses. Immunity (2008) 28:740-50. doi:10.1016/j.immuni.2008.05.001

51. Güttsches A-K, Löseke S, Zähringer U, Sonnenborn U, Enders C, Gatermann S, et al. Anti-inflammatory modulation of immune response by probiotic Escherichia coli Nissle 1917 in human blood mononuclear cells. Innate Immun (2012) 18:204-16. doi:10.1177/1753425910396251

52. Christensen HR, Frøkiaer H, Pestka JJ. Lactobacilli differentially modulate expression of cytokines and maturation surface markers in murine dendritic cells. J Immunol (2002) 168:171-8. doi:10.4049/jimmunol.168.1.171

53. Zeuthen LH, Christensen HR, Frøkiaer H. Lactic acid bacteria inducing a weak interleukin-12 and tumor necrosis factor alpha response in human dendritic cells inhibit strongly stimulating lactic acid bacteria but act synergistically with Gram-negative bacteria. Clin Vaccine Immunol (2006) 13:365-75. doi:10.1128/CVI.13.3.365-375.2006

54. Macpherson AJ, Uhr T. Induction of protective IgA by intestinal dendritic cells carrying commensal bacteria. Science (2004) 303:1662-5. doi:10.1126/ science. 1091334

55. Ruane D, Chorny A, Lee H, Faith J, Pandey G, Shan M, et al. Microbiota regulate the ability of lung dendritic cells to induce IgA class-switch recombination and generate protective gastrointestinal immune responses. J Exp Med (2016) 213:53-73. doi:10.1084/jem.20150567

56. Pone EJ, Lou Z, Lam T, Greenberg ML, Wang R, Xu Z, et al. B cell TLR1/2, TLR4, TLR7 and TLR9 interact in induction of class switch DNA recombination: modulation by $\mathrm{BCR}$ and $\mathrm{CD} 40$, and relevance to T-independent antibody responses. Autoimmunity (2015) 48:1-12. doi:10.3109/08916934.2014. 993027

57. Zeuthen LH, Fink LN, Frokiaer H. Epithelial cells prime the immune response to an array of gut-derived commensals towards a tolerogenic phenotype through distinct actions of thymic stromal lymphopoietin and transforming growth factor- $\beta$. Immunology (2008) 123:197-208. doi:10.1111/j.1365-2567.2007.02687.x

58. Iliev ID, Kitazawa H, Shimosato T, Katoh S, Morita H, He F, et al. Strong immunostimulation in murine immune cells by Lactobacillus rhamnosus GG DNA containing novel oligodeoxynucleotide pattern. Cell Microbiol (2005) 7:403-14. doi:10.1111/j.1462-5822.2004.00492.x

59. Krieg AM, Yi A-K, Matson S, Waldschmidt TJ, Bishop GA, Teasdale R, et al. CpG motifs in bacterial DNA trigger direct B-cell activation. Nature (1995) 374:546-9. doi:10.1038/374546a0

60. Blaas S, Stieber-Gunckel M, Falk W, Obermeier F, Rogler G. CpGoligodeoxynucleotides stimulate immunoglobulin A secretion in intestinal mucosal B cells. Clin Exp Immunol (2009) 155:534-40. doi:10.1111/j.1365-2249.2008.03855.x

61. Diana J, Moura IC, Vaugier C, Gestin A, Tissandie E, Beaudoin L, et al. Secretory IgA induces tolerogenic dendritic cells through SIGNR1 dampening autoimmunity in mice. J Immunol (2013) 191:2335-43. doi:10.4049/ jimmunol.1300864

62. Monteiro R. Immunoglobulin A as an anti-inflammatory agent. Clin Exp Immunol (2014) 178:108-10. doi:10.1111/cei.12531

63. Salerno-Goncalves R, Safavie F, Fasano A, Sztein MB. Free and complexed-secretory immunoglobulin A triggers distinct intestinal epithelial responses. Clin Exp Immunol (2016) 185(3):338-47. doi:10.1111/cei.12801 
64. Vlasova AN, Chattha KS, Kandasamy S, Liu Z, Esseili M, Shao L, et al. Lactobacilli and bifidobacteria promote immune homeostasis by modulating innate immune responses to human rotavirus in neonatal gnotobiotic pigs. PLoS One (2013) 8:e76962. doi:10.1371/journal.pone.0076962

65. Zhang B, Chassaing B, Shi Z, Uchiyama R, Zhang Z, Denning TL, et al. Prevention and cure of rotavirus infection via TLR5/NLRC4-mediated production of IL-22 and IL-18. Science (2014) 346:861-5. doi:10.1126/ science. 1256999

66. Hernández PP, Mahlakõiv T, Yang I, Schwierzeck V, Nguyen N, Guendel $\mathrm{F}$, et al. Interferon-[lambda] and interleukin 22 act synergistically for the induction of interferon-stimulated genes and control of rotavirus infection. Nat Immunol (2015) 16:698-707. doi:10.1038/ni.3180

67. Shao L, Fischer DD, Kandasamy S, Rauf A, Langel SN, Wentworth DE, et al. Comparative in vitro and in vivo studies of porcine rotavirus G9P [13] and human rotavirus Wa G1P [8]. J Virol (2016) 90:142-51. doi:10.1128/ JVI.02401-15

68. Ichinohe T, Pang IK, Kumamoto Y, Peaper DR, Ho JH, Murray TS, et al. Microbiota regulates immune defense against respiratory tract influenza A virus infection. Proc Natl Acad Sci U S A (2011) 108:5354-9. doi:10.1073/ pnas. 1019378108

69. Smits HH, Van Beelen AJ, Hessle C, Westland R, De Jong E, Soeteman E, et al. Commensal Gram-negative bacteria prime human dendritic cells for enhanced IL-23 and IL-27 expression and enhanced Th1 development. Eur J Immunol (2004) 34:1371-80. doi:10.1002/eji.200324815

70. Adam E, Delbrassinne L, Bouillot C, Reynders V, Mailleux AC, Muraille E, et al. Probiotic Escherichia coli Nissle 1917 activates DC and prevents house dust mite allergy through a TLR4-dependent pathway. Eur J Immunol (2010) 40:1995-2005. doi:10.1002/eji.200939913

71. Ganal SC, Sanos SL, Kallfass C, Oberle K, Johner C, Kirschning C, et al. Priming of natural killer cells by nonmucosal mononuclear phagocytes requires instructive signals from commensal microbiota. Immunity (2012) 37:171-86. doi:10.1016/j.immuni.2012.05.020

72. Fábrega MJ, Aguilera L, Giménez R, Varela E, Cañas MA, Antolin M, et al. Activation of immune and defense responses in the intestinal mucosa by outer membrane vesicles of commensal and probiotic Escherichia coli strains. Front Microbiol (2016) 7:705. doi:10.3389/fmicb.2016.00705

73. Jones MK, Watanabe M, Zhu S, Graves CL, Keyes LR, Grau KR, et al. Enteric bacteria promote human and mouse norovirus infection of B cells. Science (2014) 346:755-9. doi:10.1126/science.1257147

74. Karst SM. The influence of commensal bacteria on infection with enteric viruses. Nat Rev Microbiol (2016) 14:197-204. doi:10.1038/nrmicro.2015.25

75. Pfeiffer JK, Virgin HW. Transkingdom control of viral infection and immunity in the mammalian intestine. Science (2016) 351:aad5872. doi:10.1126/science. aad5872

76. Robinson CM, Pfeiffer JK. Viruses and the microbiota. Annu Rev Virol (2014) 1:55. doi:10.1146/annurev-virology-031413-085550

77. Kane M, Case LK, Kopaskie K, Kozlova A, Macdearmid C, Chervonsky AV, et al. Successful transmission of a retrovirus depends on the commensal microbiota. Science (2011) 334:245-9. doi:10.1126/science.1210718

78. Robinson CM, Jesudhasan PR, Pfeiffer JK. Bacterial lipopolysaccharide binding enhances virion stability and promotes environmental fitness of an enteric virus. Cell Host Microbe (2014) 15:36-46. doi:10.1016/j.chom.2013.12.004

79. Miura T, Sano D, Suenaga A, Yoshimura T, Fuzawa M, Nakagomi T, et al. Histo-blood group antigen-like substances of human enteric bacteria as specific adsorbents for human noroviruses. J Virol (2013) 87:9441-51. doi:10.1128/JVI.01060-13

Conflict of Interest Statement: The authors declare that the research was conducted in the absence of any commercial or financial relationships that could be construed as a potential conflict of interest.

Copyright (C 2017 Kandasamy, Vlasova, Fischer, Chattha, Shao, Kumar, Langel, Rauf, Huang, Rajashekara and Saif. This is an open-access article distributed under the terms of the Creative Commons Attribution License (CC BY). The use, distribution or reproduction in other forums is permitted, provided the original author(s) or licensor are credited and that the original publication in this journal is cited, in accordance with accepted academic practice. No use, distribution or reproduction is permitted which does not comply with these terms. 